\title{
Serbernes sammenstød med virkeligheden
}

Richard Swartz

\section{Mange serbere er tilbøjelige til at tro, at deres vanskeligheder skyldes en ond omverden og ikke deres egne valg. De mener, at de har retten til Ko- sovo, skønt de ikke aner, hvad de i givet fald skulle stille op med to millioner albanere}

Serberne er de sidste i Østeuropa, som endnu ikke har lært forrige århundredes store østeuropæiske lektie: at alle i denne del af Europa er tabere.

Tabere? Men serberne har altid ment, at de hørte hjemme blandt sejrherrerne. Har de ikke befriet sig selv fra både osmanner og habsburgere, været med til at vinde to verdenskrige og med deres sejre på slagmarken og omverdenens velvilje taget sig af de andre sydslaviske folk og givet dem Jugoslavien som et fælles hjem? Var de ikke de første til at sige nej til Stalin for derefter at opfinde en 'tredje vej' for at slippe for at underkaste sig Vestens kapitalisme?

Til denne serbiske selvopfattelse hører også overbevisningen om aldrig at have ført krig mod nogen af deres naboer, kun hver gang retmæssigt forsvaret sig. Desto større bliver chokket, når det viser sig, at omverdenen er af en anden mening. Den deler ikke denne opfattelse af historien, skønt serberne fremturer og nægter at revidere den. Irriteret, men dog tålmodigt, forsøger Vesten at håndtere denne serbiske trods (inat med et smukt tyrkisk låneord), mens serbernes østeuropæiske naboer medlidende eller skadefro ryster på hovedet. De ved jo bare alt for godt, at serberne befinder sig i samme affaldsspand som dem, og som de efter kommunismens fald forsøger at kravle op af.

End ikke NATOs bombekrig mod Serbien fik serberne til at indse, at deres selvopfattelse måske er autistisk og langt hinsides al europæisk virkelighed. Snarere tværtimod: in- 
genting har som disse bomber overbevist serberne om, at de har ret, og at Europa tager fejl. Lige siden har Serbien befundet sig i en dybere krise end måske nogensinde, siden staten blev til i 1800 -tallets første halvdel. Tiden er af lave: også tidligere venner er blevet fjender, falske venner som har sat sig for at lemlæste Serbien, som om landet er en koloni og ikke en suveræn stat.

Således blandes i samtidens serbiske bevidsthed manglende forståelse med aggression, selvmedlidenhed med trods, selvoptagethed med udfald mod omverdenen, alt sammen med det formål at holde selvopfattelsen uforanderligt intakt

\section{Serbiens forspildte ret}

Det er svært at argumentere mod dem, som mener at Serbien har forspildt retten til Kosovo. Konflikten mellem serbere og albanere har i praksis været akut lige siden Titos død i 1980, og den kulminere i Beograds bestræbelser i 1999 på at rense provinsen for dens albanske befolkning, den direkte årsag til NATO's luftkrig. I strid med den daværende jugoslaviske forfatning blev Kosovos autonomi i 1989 ophævet af Slobodan Milosevic, denne politiske leder, som serberne gang på gang genvalgte i frie valg, inden han i efteråret 2000 blev styrtet ved en 'revolution', som snarere fortjener betegnelsen klassisk paladskup. Men selve konflikten går længere tilbage i tiden, næsten altid med serberne som de politisk, økonomisk og militært dominerende, om end med albanerne som provinsens flertalsbefolkning i hvert fald i mindst hundrede år. I dag berører den albanskserbiske konflikt direkte spørgsmål om serbisk identitet, og de forestillinger albanerne har om en fælles nation. Det er den sidste uløste konflikt på Balkan af virkelig betydning, med potentiale til at forvandle regionen til et urocenter igen, og det må siges, at en løsning virker fjern og faktisk svær at forestille sig.

For det er ubestrideligt, at fortsat serbisk suverænitet over Kosovo efter hvad der skete under Milosevic omgående ville føre til krig. End ikke de - på papiret - meget generøse erklæringer om selvstyre, som Beograd har tilbudt, havde den mindste chance for at blive accepteret af albanerne i Kosovo. Samtidig har Beograd demonstreret, at man ikke er parat til at betragte et sådant selvstyrende, men folkeretsligt fortsat serbisk Kosovo som andet end en anomali. Der er ikke fremlagt nogen som helst planer for, hvordan en sådan selvstyrende del af staten skulle kunne integreres i den.

Årsagerne hertil ligger lige for: albanerne udgør allerede en femtedel af befolkningen i Serbien i dag og ville med deres høje fødselshyppighed snart blive en dominerende faktor i enhver serbisk stats indenrigspolitik. Men det er kun yderst få serbere, som kan forestille sig albanere 
i landets parlament (skupstina) som tungen på vægtskålen i, hvad de ser som rent serbiske anliggender, albanske programmer i det statslige fjernsyn eller dele af Beograd opkøbt af albanske forretningsmænd.

Ingen serbisk politiker af betydning ville derfor vove at foreslå en sådan løsning, eftersom nationale målsætninger på Balkan går forud for demokratiske. Og selv om også albanerne afviser en sameksistens, som i dagens Europa er det normale, kan serbernes insisteren på en enhedsstat virke mere formalistisk og hyklerisk og i hvert fald mindre praktisk end albansk suverænitet.

\section{Men hvem bliver de næste?}

Alligevel er USA's og EU's holdning dikteret mere af, hvad der opfattes som tvingende omstændigheder, end af virkelig overbevisning. At berøve en europæisk stat en stor del af dens territorium er yderst problematisk, og det hjælper ikke at som et mantra gentage, at en sådan løsning ikke må ses som et præjudikat, at Kosovo er et 'enestående tilfælde'. Enestående? Men historien er fuld af sådanne højtidelige, spidsfindige erklæringer, som blev fuldkommen ignoreret af begivenhedernes gang.

Sådanne forsikringer bør vel derfor først og fremmest betragtes som politisk peptalk og moralsk terapi for de politikere i Vesten, som plejer at udfærdige dem. I hvert fald er det svært at tro, at serbere i Bosnien og albanere i Makedonien ikke skulle påberåbe sig et suverænt Kosovo for egen regning. Ironisk nok har Vesten desuden i praksis stillet sig bag, hvad man hele tiden har hævdet at være imod på Balkan: en revision af de eksisterende grænser.

En sådan grænserevision kan desuden se ud som en ganske vist uudtalt og utilsigtet, men ikke desto mindre faktisk accept af den etniske udrensnings logik. Og selv om den overvejende er selvforskyldt fra serbisk side, er det netop denne logik, som har ført til, at så mange serbere er udvandret fra Kosovo, at der er skabt et mere end 90 procent 'rent' etnisk område, som nu 'belønnes' med selvstændighed. Det er sandt at baggrunden for krigen i Kosovo ser anderledes ud end baggrunden for krigene i andre dele af det tidligere Jugoslavien; men slutresultatet kan siges at blive det samme, også her efterfølgende accepteret af det internationale samfund: fred er kun blevet mulig ved at den etniske udrensning stort set er gennemført.

Men præcis som det er tilfældet med Balkan-krigene, bærer netop serberne også det største ansvar for de etniske udrensninger på Balkan. Havde de ikke ved det ene valg efter det andet støttet Milosevic, denne politiker der som den første bevidst forsøgte at bruge nationalismen for at undgå en europæisk demokratisering, så havde slovenere, kroater og andre måske ikke haft deres homogene nationalstater i dag. Men så- 
danne historiske ironier får sjældent nogen anerkendelse, og man skal ikke regne med at se monumenter eller torve omdøbt til Slobodan Milosevic' ære i byer som Zagreb, Sarajevo eller Ljubljana.

\section{Kosovos krigsvante nye ledere}

Albanerne står sidst i køen på Balkan. Omverdenen har for det meste ignoreret dem, og deres nationale opvågnen kom sent. Albanerne bor på Balkan spredt over fem statsdannelser (Albanien, Makedonien, Montenegro, Grækenland og Kosovo) og vil snart blive Balkans mest talrige nation næst efter rumænerne. Mange albanere opfatter det sikkert som uretfærdigt, at de endnu ikke har kunnet samles i en enkelt nationalstat. Men bortset fra spredte tilløb er det svært at få øje på et fælles program for nationen eller en sammenhængende politisk bevægelse, som ville kunne gennemføre det. Traditionelt er albanernes interesser snarere blevet defineret i regionale end i nationale termer; albanske klaner og storfamilier var irriterede over grænser (uden hvilke det er svært at forestille sig en nationalstat), som hindrede dem i at bevæge sig frit frem og tilbage i et område, de betragtede som deres.

Efter at det osmanniske imperium i begyndelsen af 1900-tallet mistede sin indflydelse i Europa, har albanerne levet mere eller mindre undertrykte af deres slaviske og græske naboer, men i selve Albanien også under et næsten halvtredsårigt kommunistisk diktatur, det værste som Europa oplevede. Først da NATO i 1999 havde brug for nogen til at slås mod serberne også på landjorden $\mathrm{i}$ Kosovo kom deres store historiske chance. Washington lovede til gengæld albanerne selvstændighed, og nogle, heriblandt mistænksomme naboer, har siden betragtet Kosovo som et albansk Piemonte og den første begyndelse til en fremtidig storalbansk statsdannelse.

I hvert fald er albansk politik i Kosovo for første gang siden 1945 domineret af en ung generation, som med våben $\mathrm{i}$ hånd har forsvaret sit land og samtidig gjort sig fri af en ældre generations pragmatiske, patriarkalske ledelse. Dennes sidste repræsentanter - som Azem Vlasi eller Ibrahim Rugova - var påvirkede at titoistiske forestillinger, som dog gav et vist spillerum for dialog, kompromis og forhandlingsløsninger. Med den unge generations politiske emancipation er alt dette forsvundet. Rugova blev endog stemplet som 'forræder', inden han døde.

Disse unge ledere bebrejder den ældre generation, at den med sin politiske strategi ikke opnåede noget som helst, en noget kategorisk dom i betragtning af de fremskridt, som trods alt skabtes i det sidste årti under Tito. Men denne nye ledelse med en opvækst præget af undertrykkelse, arbejdsløshed, eksil og kriminalitet - Carla del Ponte taler om 
'gangstere i uniform' - er for en stor del resultatet af netop den serbiske politik, og hvordan man end ser på det, er dette hvad både serbere og det internationale samfund har at holde sig til. Forhåbningen er vel, at denne nye politiske klasse i mere end blot symbols betydning bliver $\mathrm{i}$ stand til at skifte uniformen ud med jakkesæt og slips.

Den politiske kultur som råder på Balkan taler dog næppe for det. Et kompromis ses her som et tegn på svaghed eller ligefrem underkastelse. I stedet for en demokratisk diskurs foretrækker man politiske nulsumsspil, hvor egen gevinst modsvares af modstanderens tab. Det gælder om at sejre og besejre. Det siges, at serberne 'inderst inde' skulle være på det rene med, at Kosovo er tabt. Men det er ikke det samme som, at de vil finde sig i det. Serberne har altid vidst, at de i 1389 tabte slaget på Solsortesletten (Kosovo Polje); men det har ikke hindret dem i at i århundreder tro på og virke for en sejr hinsides slagmarken.

Dagens Serbien lever langt stærkere end andre samfund i $\emptyset_{\text {steuropa }} \mathrm{i}$ en både mytisk og realistisk-modernistisk verden, hvor den meget reelle konflikt omkring Kosovo paradoksalt forstærker netop myten. Europa - EU - har forstået meget lidt af dette. Serbien opfattes ganske vist som noget besværlig, men dog som en post i regnskabet, hvor man kan viske lidt ud, hvorefter alt er i orden igen. Man vil ikke se virkeligheden: et folk som giver omverdenen skylden for alle sine ulykker, ude af stand til selvkritik og selverkendelse, en stat hvor ekstreme nationalister udgør parlamentets største parti, hvis retorik er fuld af ord som ære, blod, herkomst og grænser, og hvis leder sidder i en celle i Haag anklaget for krigsforbrydelser.

I samme parlament sælges hans og andre krigsforbryderes bøger åbenlyst; i den seneste vil Vojeslav Seselj på mere end tusinde sider påvise, at kroater egentlig ikke er andet end serbere, som af Vatikanet er blevet forført til katolicismen. En sådan partileder må være enestående i dagens Europa.

Alligevel bagatelliserer politikere $\mathrm{i}$ Vesten sådanne kendsgerninger, hvis de overhovedet lægger mærke til dem. Omstændighederne kan dog komme til at spille netop disse nationalistiske kræfter kort i hænde, og 'omstændighederne' er her bare et andet ord for Kosovo.

Richard Swartz er svensk journalist og forfatter, baseret $i$ Stockholm (Svenska Dagbladet), Wien og på Istrien $i$ Kroatien. Hans arbejdsområde gennem en menneskealder er Øst- og Centraleuropa og Balkan.

Artiklen er afleveret inden uafhengighedserklaringen den 17. februar 2008.

Oversat fra svensk af Klaus Carsten Pedersen. 